\title{
MTHEMBU v LETSELA: THE NON-DECISION ${ }^{1}$
}

\section{AM Janse van Rensburg ${ }^{2}$}

\section{Introduction}

The debate concerning the apparent conflict between equality (section 9 of the Constitution of the Republic of South Africa 108 of 1996) and culture (sections 30 and 31 of the 1996 Constitution) is ongoing. This debate, in many ways foreseen, was pre-empted by the Constitutional Court per Sachs $\mathrm{J}$ in Du Plessis and Others $v$ de Klerk and Another, ${ }^{3}$ when he stated at paragraph [189] that " . . sooner or later, the question of the relationship between the Constitution and customary or indigenous law will have to be confronted." The Court went further to predict a possible outcome to this conflict, when it found that:

"...patriarchal principles which underlie much of indigenous law would be outlawed by the Bill of Rights, thereby undermining the core of indigenous law." 4

Until recently this conflict remained part of the paper war between, amongst others, traditionalists (striving to preserve the traditional way of life), and particularly feminists (fighting to eradicate all bastions of patriarchy, such as primogeniture and the negotiation of lobolo). In 1997, the court caught its first glimpse of this troubled war. In Ryland $v$ Edros ${ }^{5}$ the court, per Farlam J, stressed that there is a duty placed on the judiciary to apply the "values of equality and tolerance of diversity", which "radiate . . . the concepts of public policy and boni mores". In this decision the court took into account the plural nature of our society, when it

1 Based on a paper read at the Congress of the Society of Law Teachers of Southern Africa (SLTSA) 2000 held in Durban on 3-6 July 2000.

2 Lecturer: Department Private Law, Vista University (Bloemfontein).

3 Du Plessis and Others $v$ de Klerk and Another 19963 SA 850 (CC).

4 Ex Parte Chairperson of the Constitutional Assembly: In re Certification of the Constitution of the Republic of South Africa 19964 SA 744 (CC) par [200].

5 Ryland $v$ Edros 19972 SA 690 (C) at 709 B-C. 
interpreted the Constitution, as advocated by Farlam J.

In the Mthembu-decisions, the judiciary was faced with yet another opportunity to give effect to this value of diversity, but the court, at its own admission, sometimes expressly, sometimes implicitly, had struggled in all three the cases, to give effect to the duty illustrated in Ryland's case.

In the first Mthembu-case ${ }^{6}$ the court found itself unable, due to a lack of information, to make an order relating to the validity of a customary marriage, and subsequently referred the matter for oral evidence. The court in the second Mthembu-case ${ }^{7}$ found in favour of the customary rules of intestate succession, but adhered to the parties' submission that it was common cause that no customary marriage existed. It was hoped that the appeal ${ }^{8}$ would give matters a different complexion, but unfortunately the court decided the matter without referring to the existence of a valid customary marriage.

Two very important questions were raised in the Mthembu-decisions, namely the influence and meaning of the principle of primogeniture, and whether a valid customary marriage was contracted between the deceased and the appellant. In order to accurately and effectively facilitate an analysis of the three decisions, one has to take note of the customary rules of intestate succession and the requirements for a valid customary marriage.

The question re the validity of the marriage contracted between the deceased and the appellant, the effect of the illegitimacy of the child Thembi, born from the union, as well as the manner in which the respective courts and counsel dealt with the issue of validity, forms the crux of this critique. The purpose of this note is to analyse the decisions of the respective courts, with reference to a discussion of the rules of customary intestate succession and the requirements for a valid customary marriage, and then to propose a possible different outcome which, if applied

$6 \quad$ Mthembu $v$ Letsela 1997 (2) SA 936 (T).

$7 \quad$ Mthembu $v$ Letsela 1998 (2) SA 675 (T).

$8 \quad$ Mthembu $v$ Letsela 2000 (3) SA 867 (SCA). 
by the courts, would have been beneficial to all the parties involved. This then leads to a proposal of an alternative remedy to the postulated problem.

\section{Customary rules of intestate succession}

The customary rules of intestate succession are based on two predominant features. The first is the continuation of the family lineage of the husband as the family head, along with the principle of primogeniture, according to which the eldest male descendant of the deceased succeeds to the property, position, status and standing of the deceased. ${ }^{9}$ The second is the concept of the family and the collective rights and responsibilities within each respective family grouping. ${ }^{10}$ This sentiment is eloquently described by Jack Simons ${ }^{11}$ as follows:

Male primogeniture is consistent with the structure and functions of the joint family. The general heir, who succeeds to the office as well as to an estate, must be a male, because only a man can be a head of a household in the traditional society. Intestate succession through the male line forestalls the partitioning of an estate, and keeps it intact for the support of the widow, unmarried daughters and younger sons.

This system is further entrenched by the provisions of the Black Administration Act 38 of 1927 (hereinafter 'the 1927 Act'), read with the provisions of the Intestate Succession Act 81 of 1987, which clearly states in section 23 thereof, that all moveable property belonging to a black person will, upon his death, devolve and be administered under "black law and custom". Immovable property will, in accordance with custom, devolve upon one male person. The State President (as the office was then known) could in terms of the 1927 Act issue regulations prescribing the manner in which the estates of deceased black people were to be administered and distributed. Government Notice R200 of 1987 (The regulations for the administration and distribution of the

9 Olivier ea Indigenous Law 147-148.

10 Bekker Customary Law in Southern Africa 273.

11 Simons African Women 239. 
estates of deceased Blacks) was issued in terms of this section. Regulation 2 of the Notice regulates the situation where the deceased left no valid will, or dies intestate (a regulation, which was, in the third Mthembu-case, found to be in keeping with public policy, as will be indicated below).

These rules of succession are clearly geared towards the perpetuation of male dominance, albeit for the perseverance of family unity or economic stability. The heir has the same standing and status as the deceased had. Plainly stated - he steps into the shoes of his predecessor. He has the function of guardian over minors, he controls the family property, he is burdened with the same responsibility with regards to the payment and reception of lobolo, debts and other fines, and the maintenance of all the inhabitants of the kraal, specifically the widow and her children.

The widow and her children are entitled to proper maintenance and the successor has the right to allocate a place of residence to her. Even though it is a cardinal rule, with certain exceptions, that women may not inherit from men, this does not leave the widow to her own devices. She has a recognised claim for maintenance, despite the fact that she has no actual inheritance. ${ }^{12}$ This duty to maintain is not taken lightly, and rightly so, for, to a certain extent, the family head lives on through his heir.

This seeming special treatment reserved to the widow is based on the fact that the death of the husband does not ordinarily dissolve a customary marriage, and that the wife (now the widow) remains a wife to the deceased and a member of his family. All this is premised on the fact that the widow and the deceased were indeed legally married, for the duty to maintain reaches only as far as 'legitimate' widows, and for that matter, 'legitimate' children.

\section{The requirements for a valid customary marriage and the importance of lobolo}

In order to ascertain whether the union constituted a valid customary marriage, and therefore

12 Bennett African Customary Law for Southern Africa 416. 
whether the woman was the legitimate wife and widow of the deceased, one has to determine whether the marriage complied with the requirements for validity, such as the consent of the father of the bride, the actual transfer of the bride and, the highly controversial lobolo arrangement.

Bride-wealth or lobolo has always been a very important part of the marriage negotiations. The physical delivery of lobolo is not an essential requirement for validity, but the subsequent nondelivery can give rise to grounds for the annulment of the marriage. ${ }^{13}$ Its importance is illustrated by the fact that the marriage is regarded as 'incomplete', or that the status of the children born out of such a marriage is ultimately affected by the non-compliance with the lobolo requirement, in that they are considered to be illegitimate. ${ }^{14}$

\section{The importance of the Mthembu-decisions}

It is at this juncture that the importance of the Mthembu-cases becomes apparent. Tebalo Wilson Letsela (hereinafter 'the deceased') died on 13 August 1993. At the time of his death he was the holder of a 99 year leasehold title in respect of a fixed property situated in Vosloorus. He lived on the property with the appellant (Mildred Hleziphi Mthembu) and her two minor daughters. One of these children, Thembi, was born on 7 April 1988 of an intimate relationship between the appellant and the deceased. The deceased was also survived by his father (the first respondent), his mother and his three sisters. The deceased's father and mother, along with one of his sisters and her children lived with the deceased, the appellant and her daughters on the property.

The appellant alleged that she and the deceased entered into a customary marriage on 14 June 1992 (less than 14 months before his death). She supported this allegation with the receipt for the first instalment of R900.00, towards her lobolo of R2000.00. The balance was to be paid soon thereafter. The deceased, however, died before it was paid. The appellant claimed that she is the widow of the deceased, on the grounds that a valid customary marriage was entered into by

13 Olivier ea Indigenous Law 40. 
herself and the deceased, and that her child was therefore legitimized by their subsequent nuptials.

The matter first came before Le Roux $\mathrm{J}$ (the first Mthembu-case), who was unable to resolve the factual dispute relating to the existence or otherwise of a customary marriage between the appellant and the deceased. The court referred the issue for oral evidence. The issue was accordingly postponed sine die.

In the second Mthembu-case it was accepted that because no evidence was tendered from either side, that the matter was to be decided on the assumption that there was indeed no such marriage between the parties.

The Supreme Court of Appeal per Mpati J found (at par [17]) that

... (t)he position with regard to an illegitimate child is that he or she is legitimized by subsequent payment of dowry or bridewealth and marriage of the parents. (Emphasis in the original)

and that there

... must . . be a marriage and not merely a payment of bridewealth or part of it for the child to be 'transferred' into the father's family.

It followed that, despite the fact that part of the lobolo was paid, Thembi was not legitimized, because no valid marriage existed between the appellant and the deceased. It was found that she therefore belonged to the family of her mother. The matter was accordingly decided on the premise the Thembi is the deceased's illegitimate child (at par [8] of the SCA judgment), and therefore that

$\ldots$ in terms of this system of succession, whether or not Thembi is the deceased's legitimate child, being female, she does not qualify as heir to the deceased's

14 Olivier ea Indigenous Law 32-34. 
estate. Women generally do not inherit in customary law.

\section{The question re constitutionality}

Even though the subject-matter of the discussion is clear from the above, namely that it was considered common cause in all the courts that no customary marriage existed, and that Thembi is therefore illegitimate, it is important to mention the issues that were indeed decided, as its importance will become apparent in the discussion below.

In both the first and the second Mthembu cases, as well as in the SCA decision, it was argued that the customary rule of succession, i.e. the principle of primogeniture, is grossly discriminatory, in that it not only discriminates against black women and girls, but also against children born out of wedlock. The claim was based on an alleged contravention of subsections 8(1) and (2) and section 14 of the 1993 Constitution.

In the first Mthembu-case Le Roux J found that, considering that the duty to maintain the widow and her children and the other members of the deceased's household is a necessary counterpart of the principle of primogeniture, the differentiation between men and women ceases to be unfair. Therefore the evidence of prima facie discrimination is refuted by the concomitant duty to support. $^{15}$ In the second Mthembu-case Mynhart $\mathrm{J}$ dismissed the application to declare the customary rule of primogeniture, which generally excludes African women from intestate succession and regulation 2 of GN R200 of 1987 issued in terms of section 23(10) of the 1927 Act, invalid on the ground of its inconsistency with the provisions of the 1993 Constitution. The court found that the existence of the concomitant duty to support, which was placed on the heir, rendered such differentiation justifiable.

In the case before the Supreme Court of Appeal, counsel for the appellant, persisted in centring their argument on the following propositions: first that Thembi would have succeeded by

15 Mthembu v Letsela 1997 (2) SA 936 (T) at 945H-946C. 
intestate succession at customary law to her deceased father's estate but for the fact that she is female, and secondly, that the principle of primogeniture is offensive to public policy or natural justice, because it is incompatible with the value of equality.

The Court dismissed the first proposition, namely the allegation of gender discrimination, with the following admission at par [33]: "The gender discrimination [question] is not reached in this case" because in casu it would amount to an academic exercise only, and that " . . it is not desirable to address a question of such constitutional importance . . ." in these circumstances. The second proposition was disposed of with the same ease, as it noted that regulations issued in terms of section 23(10) of the Black Administration Act, are indeed legislative recognition of "black" laws and custom, allowing black people the opportunity to choose how they wish their estates to be devolved upon their death, either by means of customary rules or by means of a will. The court further found (at par [24]) that, taking this aspect into account,

... it is difficult to see how a regulation which respects the [choice of the individual] can be said to be unreasonable and ultra vires at common law.

\section{The non-decision}

It is not the ultimate SCA decision, based on the above-mentioned propositions, that forms the basis of my critique, but rather the manner in which this case was dealt with from the outset, viz. the persistence of counsel that the court addresses the possible unconstitutionality of the rules of African customary law, at the expense of the parties seeking remedy. It is not my intention to deal with the question of constitutionality, but rather with the lack of recognition given to the

principles underlying, to my mind, the core issue of this case, namely the question whether a valid union existed between the appellant and the deceased, thereby allowing Thembi her rightful claim to maintenance by her deceased father's heir. 
Bennet ${ }^{16}$ states clearly that in customary law the husband and his family have full parental rights to any children born to the wife during the marriage, provided that they fulfilled their obligations under the bridewealth agreement. It goes without saying that, in terms of custom, in the instance where these marriage obligations were not met, the parental rights will befall the maternal family, and the child born from such a union is considered illegitimate, and will not be able to inherit from the paternal family.

In Mthembu's case the marriage between the deceased and the appellant was considered to be null, for one of the prerequisites for validity, namely the payment of the entire lobolo amount (per the SCA), was not met, a fact considered common cause by the parties, and which was therefore not argued in any of the courts. The consequence of this state of affairs is that, from the outset, Thembi was labelled illegitimate, and Mildred (the mother) was excluded from benefiting from the duties of the heir. The court quoted from an article by Burman ${ }^{17}$ to substantiate its contention that the failure to comply fully with the prerequisite lobolo-payment, will affect the legitimacy of children born from such marriages. Burman stated that

. . . (i)n customary law a child born in a customary union is presumed to be legitimate and thus part of the father's family. However, as outlined above, the crucial element in the marriage which transfers the child into the father's family is not the ceremony, as in civil law, but the payment of bridewealth, at least in part. (Emphasis in SCA decision.)

With respect I differ from the interpretation given by the court to the cited passage, specifically as to the meaning of the underlined words. It is my submission that a child born within a customary marriage is presumed to be legitimate and thus part of the father's family, irrespective of the lobolo amount paid. This statement cannot be applied in an unqualified manner - even though actual delivery of the lobolo is not cited as an essential requirement, it is trite that the

16 Bennett African Customary Law for Southern Africa 289.

17 Burman 1991 Acta Juridica 41. 
later non-compliance with the payment obligation can render such a union null, and ultimately affect the status of the children. Therefore if the requisite marriage payments are not made, parental rights are bound to be uncertain. It is uncertain what period will constitute a reasonable period before the sanction of nullity strikes at the validity of the marriage. It has to be kept in mind that a customary marriage is by no means a single event, but rather a protracted ritual, commencing with the engagement negotiations and sometimes concluding with the delivering of the lobolo. This is not a fixed ritual. The marriage agreement is a communal affair, involving two family groupings, and the format is open to the whims of the parties involved. There is in principle nothing to prevent them from making another arrangement if they wished. They have to comply with the essentialia of a valid marriage, which entails, amongst other things, that lobolo must be negotiated. The union is considered valid as long as these requirements are met. This sentiment is echoed by Discussion Paper 74 of the South African Law Commission on Customary Marriages ${ }^{18}$ at page 43 where it is stated that

... (e)ven in cases where bridewealth was considered essential, the courts did not specify whether the goods had to be physically delivered or whether a mere agreement sufficed. In practice, it proved impossible to insist on delivery, for the husband's ability to pay had to be taken into account.

It is submitted that, given time, the deceased would have complied with the bridewealth obligations. It is further submitted that a valid customary marriage was contracted between the deceased and the appellant. The submission is based on the following propositions: in casu the deceased promised to fulfil the lobolo payment obligation. He died before he could fulfil the entire promise, but after he paid more than $45 \%$ of the lobolo amount. This fact, along with the notion that the best interest of the child must at all times be served, must surely serve as sufficient motivation to consider that a valid marriage existed, and therefore that Thembi was indeed legitimized by the subsequent marriage of her parents.

18 Part of Project 90 re the Harmonisation of the Common Law and the Indigenous Law. 


\section{An alternative remedy}

Given the conclusion of the court that no valid customary marriage existed between the deceased and the appellant, an alternative approach is proposed which would have, it is submitted, served the best interests of all the parties involved. This alternative, via a regulation, found by the SCA to be in keeping with the principles of natural justice and public policy, was never argued but could have been applied successfully.

Regulation 2 of Government Notice R200 of 1987 provides in subsection (d) thereof that

... (w)hen any deceased Black is survived by any partner -

(iii) who was at the time of his death living with him as his putative spouse;

... and the circumstances are such as in the opinion of the Minister to render the application of Black law and custom to the devolution of the whole, or some part, of his property inequitable ... the Minister may direct that said property ... shall devolve as if the (parties) . . . had been lawfully married out of community of property, whether or not such was in fact the case ... and as if the said Black person had been a European. (My emphasis.)

Regulation 2 states clearly that an intestate estate will dissolve according to customary law, unless the Minister determines otherwise, if the application of the customary rules of intestate succession proved inappropriate or inequitable. This determination can be made on application by the surviving putative spouse who was living with the deceased at the time of his death. The determination is to the affect that the common law principles of intestate succession be applied as if the parties had been lawfully married out of community of property. This would render section 1(1)(c) of the Intestate Succession Act 81 of 1987 applicable.

A putative marriage comes into existence when one or both of the parties bona fide believe that a lawful marriage was indeed contracted; or were bona fide unaware of the existence of a fact nullifying their union, such as the non-compliance of an essential requirement. Such a 
shortcoming renders the marriage contract null and $a b$ initio void, but irrespective of this fact, the children born out of such a union are regarded to be legitimate.

It is submitted that, in the event that it is found that a marriage was never contracted due to a non-compliance with the essentialia of a valid marriage, viz the payment of the full lobolo amount (as was the case in the Mthembu-decisions), the parties were putative spouses, to the extent that the appellant was under the bona fide impression that she was the legal wife of the deceased, as a result of the part payment of the agreed lobolo amount. It is further submitted that, given the bona fides of the appellant, this matter calls for a determination, in terms of regulation 2, by the Minister or an appropriate functionary, on the application by the appellant.

Owing to the status of the marriage after such an application and the determination by the Minister regarding the applicability of the common law, the estate of the deceased would devolve as if the parties who contracted the union were "Europeans", and married out of community of property. Based on this fact it is submitted that the appellant would, in terms of section 1(1)(c) of the Intestate Succession Act, have had a legitimate claim to half of the difference in accrual, as well as a child's share or an amount to the value of R125 000.00, whichever is the larger amount. Her child on the other hand would also have benefited under the provision mentioned, irrespective of her illegitimate standing (section 1(2)). It can also be argued that the appellant's other daughter was adopted by the deceased through the payment of the lobolo, and that the child became the child of the deceased. ${ }^{19}$ This child would also have benefited from the intestate estate. ${ }^{20}$

\section{Conclusion}

Were the approach that Thembi should have been afforded the benefit of a legitimate child, her grandfather, as the eldest male heir of the deceased, would have been duty-bound to maintain her and her mother. This would have ensured the correct application of the principle of

19 Thibela v Minister van Wet en Orde 19953 SA 147 (SCA). 
primogeniture and the concomitant duty to support the household of the deceased.

It is submitted that the interests of both the parties, especially that of the minor child, would have been served best if the marriage was regarded to be valid from the outset, irrespective of the fact that the full lobolo amount was never paid. This is based on the fact that the delivery of lobolo is not set down as an essential for validity, that the best interest of the child must at all times be served and that the deceased died before he could fulfill his promise to pay the full amount.

Were the second approach followed, viz a determination made in terms of regulation 2, the appellant, as the putative spouse of the deceased, would have been able to inherit under the common law principles of intestate succession. More specifically section 1(1)(c) of the Intestate Succession Act would have been made applicable as the deceased is survived by a spouse and a child, and, also, even the adopted child of the deceased.

If the argument of the courts is to be followed, namely that no valid marriage existed between the parties, it is submitted that the available remedy, namely regulation 2, which was found to be in keeping with the principles of natural justice and public policy, ought to have been applied to the application of the appellant, and that the matter should have been referred back to the court of first instance for an order to be made to the effect that the appellant be regarded as the putative spouse of the deceased, and therefore that his immoveable property be devolved onto her, in accordance with the common law.

These cases, as indicated above, serve as a prime example of the consequences faced by the parties, when the courts and, to a large extent, counsel, attempt to force a decision on the cultureequality issue. The application of customary law should not be ignored. Through the application of for example section 1(1) of the Laws of Evidence Amendment Act 45 of 1988 (or similar tools), a court might call upon an expert witness to give evidence as to the existence or not of a valid customary marriage between the deceased and the appellant. 
It is clear that Thembi could have been adequately protected, but in the outcome she was left without an inheritance and without the support that she needed. In future it is hoped that the following caveat be kept in mind: one should never lose sight of the individual cause, when faced with the ever-present question of what weighs the heavier, equality or culture, and one should keep the approach advocated by Farlam J expressed in Ryland $v$ Edros (quoted above) in mind, and thus cultivate a culture of understanding, in a country characterized by diversity. 


\section{Bibliography}

Bekker Customary Law in Southern Africa

Bekker JC Seymour's Customary Law in Southern Africa 5th edition (Juta Cape Town 1989)

Bennett African Customary Law for Southern Africa

Bennett TW Sourcebook of African Customary Law for Southern Africa (Juta Cape Town 1995)

Burman 1991 Acta Juridica

Burman S "Illegitimacy and the African family in a changing South Africa" 1991 Acta Juridica 36

Olivier ea Indigenous Law

Olivier NJJ ea Indigenous Law (Butterworths Durban 1995)

Simons African Women

Simons J African Women (Hurst and Co London 1968)

\section{Register of acts}

Black Administration Act 38 of 1927

Constitution of the Republic of South Africa 1996

Intestate Succession Act 81 of 1987

Laws of Evidence Amendment Act 45 of 1988

\section{Register of cases}

Du Plessis and Others v de Klerk and Another 19963 SA 850 (CC) 
Ex Parte Chairperson of the Constitutional Assembly: In re Certification of the Constitution of the Republic of South Africa, 199619964 SA 744 (CC)

Mthembu v Letsela 1997 (2) SA 936 (T).

Mthembu v Letsela 1998 (2) SA 675 (T) 376-377.

Mthembu v Letsela 2000 (3) SA 867 (SCA).

Ryland v Edros 19972 SA 690 (C)

Thibela v Minister van Wet en Orde 19953 SA 147 (SCA) 